\title{
Research priority of the potential earthquake on the java island using decision making analysis
}

\author{
Wien Lestari ${ }^{1}$, Amien Widodo ${ }^{1}$, Firman Syaifuddin ${ }^{1}$ and Dwa Desa Warnana $^{1}$ \\ ${ }^{1}$ Geophysical Engineering Department, Institut Teknologi Sepuluh Nopember, Surabaya, East Java
}

\begin{abstract}
Referring to the Indonesian earthquake source and hazard map published by the National Earthquake Center (Pusgen) in 2017, it was stated that there were 34 active faults on the island of Java and could potentially be a source of earthquakes with earthquake strength more than the $6.5 \mathrm{M}$ scale. Each potential source of earthquake needs to be carried out detailed research on each fault that is declared active so as to reduce uncertainty in the seismic hazard analysis. Due to limited funding and human resources researching, it is necessary to make research priorities based on the level of urgency. By utilizing decision making analysis techniques, priority of research is carried out by considering several aspects, such as the magnitude of the earthquake that may occured possible economic impact factors, population density and the level of importance of a region on a national and international scale. From the modeling results, it is shown that faults that have the potential to become earthquake sources that are located near large cities are a top priority for detailed research such as the Lembang, Semarang and Surabaya Faults.
\end{abstract}

\section{Introduction}

The island of Java which is located on the north of the subduction between the two plates namely the IndoAustralian Plate and the Eurasian Plate has several tectonic faults as a form of stress accommodation produced by subduction in the south [1]. According to [2], a tectonic fault is a local deformation zone that accommodates plate movement through aseismic creeping at certain depths and earthquake or creeping in the shallower layers. The structures on Java Island had two main trends where the basement structures tends to have the northeast-southwest trend (the Meratus trend) and the surface structures tend to have the east-west trend (figure 1).

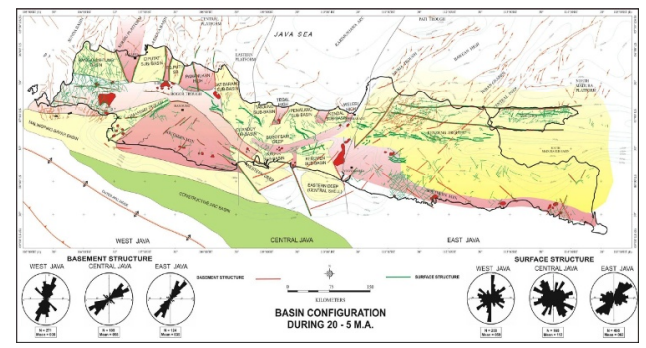

Fig. 1. Main structures in Java Island

\subsection{Active land faults on Java Island based on GPS data}

Several previous Global Positioning System (GPS) studies in Java were conducted by focusing on local deformation studies in the main fault areas such as Cimandiri Fault, Lembang Fault and Baribis Fault $[3,4,5]$. [6] conducted a study of the GPS method in the Kendeng Fault, which is an active fault that extends from the eastern part of East Java to the western part of Central Java which is active every year with a $5 \mathrm{~mm} /$ year velocity. Muria Fault in Central Java is an active fault that extends from the southwest to the northeast with the upward fault mechanism. [7] performed a calculation of the Muria fault rate using elastic dislocation assumptions. [8] conducted GPS observations of the active movement of Opak faults which resulted in the Yogya Earthquake on May 27, 2006 with magnitude 6.4 having a sliding fault mechanism at a rate of 4-6 $\mathrm{mm} /$ year. Some of the identified faults and their speed in Java Island as a result of GPS method can be seen in figure 2 .

\footnotetext{
* Corresponding author: wienlestari02@gmail.com
} 

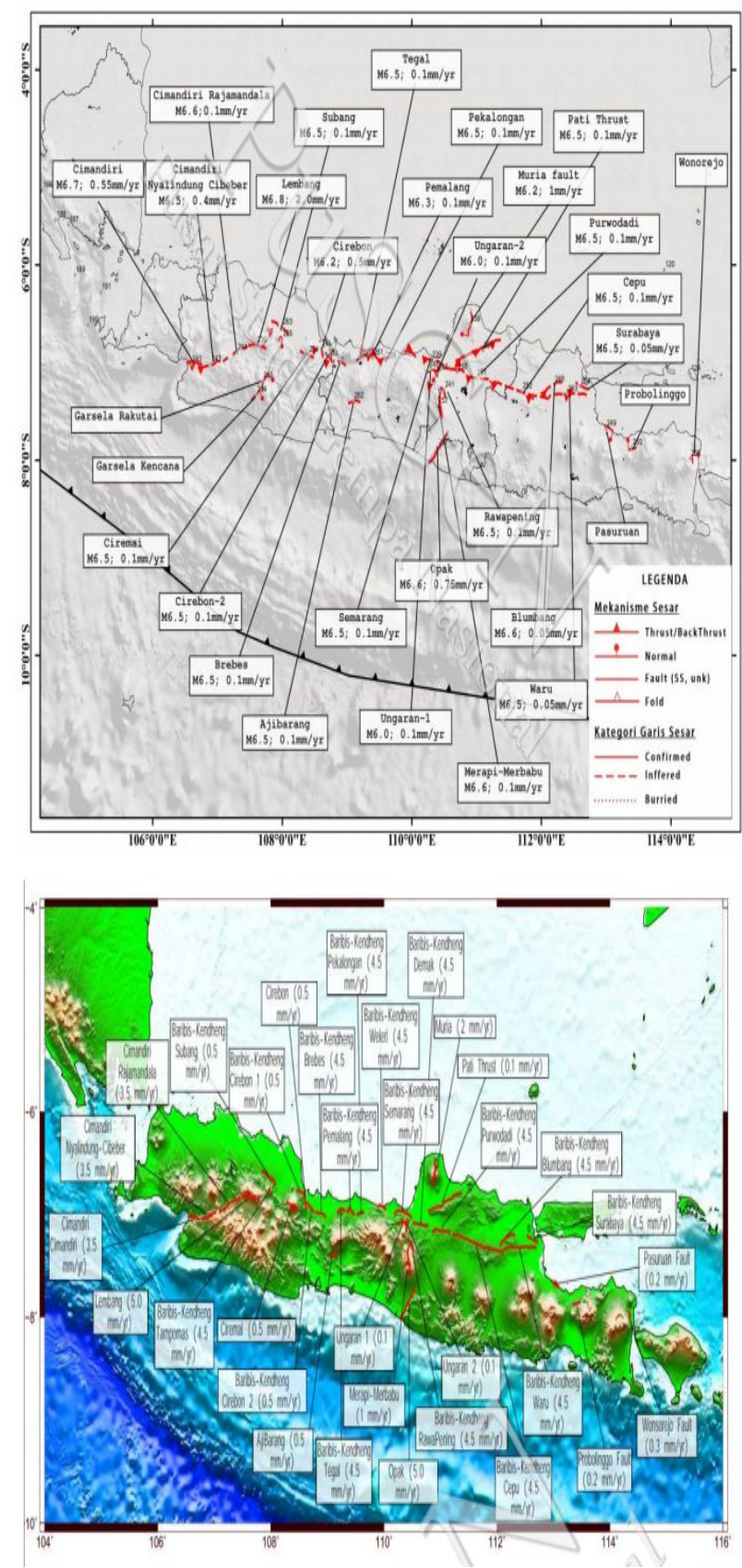

Fig. 2. Active fault segment shear rates on Java Island

\subsection{Decision Making Analysis}

Decision making is a study to identify and choose alternatives that have the highest probability of success and are most suitable for purpose. Decision-Making Tools and techniques suggested the analyzing and prioritizing issues in your needs assessment process and, ultimately, for deciding to take action [9]. There are tools to support the decision-making process below:

1. Nominal Group Technique

2. Multicriteria Analysis

3. Tabletop Analysis

4. Pair-Wise Comparison

5. $2 \times 2$ Matrix Decision Aids

6. Fishbone Diagrams
7. Root Cause Analysis

8. Fault Tree Analysis

Decision making methods that used in this paper is muticriteria analysis which is a valuable tools that offer a systematic and quantitative comparison across multiattribute utility. Variables in the analysis can each be given a weighting that reflects the priorities of the project [10]. The process of multicriteria analysis could be started from identify the most important criteria to making decision and the performance criteria required of alternative solutions. Typically, consider no more than five to eight attributes for any decision.

\section{Methodology}

A general decision making process can be divided into the following steps $[11,12]$ :

1. Identify the problem

2. Decide requirements

3. Establish goals

4. Recognize alternatives

5. Specify Criteria

6. Choose a decision making tools

7. Assess alternatives againts criteria

8. Validate solutions againts problem statement

Depending on the context of your decision and as a useful technique, apply weighting to the diverse criteria. The weights differentiate criteria according to their relative importance to the decision. It is important to use the same scale for each attribute. Create a table or spreadsheet with the performance attributes listed in the columns along the top and the potential solutions listed in the rows. For each alternative intervention or activity, include an estimate for each performance criterion. Review the result of analysis. As a useful approach, consider a combination of alternative activities rather than viewing each option as mutually exclusive.

The number of active faults on the Java Island contained in the 2017 earthquake source and danger map of Indonesia are 34 active faults which are divided into several fault segments. Table 1 performed multicriteria analysis for fault priority decision.

Table 1. Muticriteria analysis of faults priority

\begin{tabular}{|c|c|l|}
\hline Skor & Magnitude & \multicolumn{1}{c|}{ Region } \\
\hline 3 & $\mathrm{M}>=4-5$ & $\begin{array}{l}\text { Big cities/Capital of the province, } \\
\text { very densely populated, Modern and } \\
\text { complete infrastructure, middle-high } \\
\text { economic level, middle-high } \\
\text { education level }\end{array}$ \\
\hline 2 & $\mathrm{M}>=2-3$ & $\begin{array}{l}\text { district, low-middle education level, } \\
\text { relatively dense population, low- } \\
\text { medium economic level, low- } \\
\text { medium education level, Relatively } \\
\text { good infrastructure }\end{array}$ \\
\hline 1 & $\mathrm{M}>=0-1$ & $\begin{array}{l}\text { sub-district, low-medium education } \\
\text { level, fewer population, low-medium } \\
\text { economic level }\end{array}$ \\
\hline
\end{tabular}




\section{Result}

Table 2 described the active faults on the Java Island and its magnitude.

Table 2. Land Fault Segment on Java Island and its Magnitude

\begin{tabular}{|c|c|c|c|c|}
\hline No. & \multicolumn{4}{|c|}{ Active Faults } \\
\hline & Main Fault & Segment & Type & Magnitude \\
\hline 1 & $\begin{array}{l}\text { Alternative } 1 \\
\text { Cimandiri } \\
\text { Fault }\end{array}$ & Cimandiri & $\mathrm{R}$ & 3.5 \\
\hline 2 & $\begin{array}{l}\text { Alternative } 2 \\
\text { Cimandiri } \\
\text { Fault }\end{array}$ & $\begin{array}{l}\text { Nyalindung- } \\
\text { Cibeber }\end{array}$ & $\mathrm{R}$ & 3.5 \\
\hline 3 & $\begin{array}{c}\text { Alternative } 3 \\
\text { Cimandiri } \\
\text { Fault }\end{array}$ & Rajamandala & SS & 3.5 \\
\hline 4 & $\begin{array}{c}\text { Alternative } 4 \\
\text { Lembang } \\
\text { Fault }\end{array}$ & Lembang & SS & 5 \\
\hline 5 & $\begin{array}{c}\text { Alternative } 5 \\
\text { Baribis- } \\
\text { Kendeng Fault }\end{array}$ & Subang & $\mathrm{R}$ & 0.5 \\
\hline 6 & $\begin{array}{c}\text { Alternative } 6 \\
\text { Baribis- } \\
\text { Kendeng Fault }\end{array}$ & Cirebon-1 & $\mathrm{R}$ & 0.5 \\
\hline 7 & $\begin{array}{c}\text { Alternative } 7 \\
\text { Baribis- } \\
\text { Kendeng Fault }\end{array}$ & Cirebon-2 & $\mathrm{R}$ & 0.5 \\
\hline 8 & $\begin{array}{c}\text { Alternative } 8 \\
\text { Baribis- } \\
\text { Kendeng Fault }\end{array}$ & $\begin{array}{l}\text { Karang } \\
\text { Malang }\end{array}$ & $\mathrm{R}$ & 0.5 \\
\hline 9 & $\begin{array}{c}\text { Alternative } 9 \\
\text { Baribis- } \\
\text { Kendeng Fault }\end{array}$ & Brebes & $\mathrm{R}$ & 4.5 \\
\hline 10 & $\begin{array}{c}\text { Alternative } 10 \\
\text { Baribis- } \\
\text { Kendeng Fault }\end{array}$ & Tegal & $\mathrm{R}$ & 4.5 \\
\hline 11 & $\begin{array}{l}\text { Alternative } 11 \\
\text { Baribis- } \\
\text { Kendeng Fault }\end{array}$ & Pemalang & $\mathrm{R}$ & 4.5 \\
\hline 12 & $\begin{array}{c}\text { Alternative } 12 \\
\text { Baribis- } \\
\text { Kendeng Fault }\end{array}$ & Pekalongan & $\mathrm{R}$ & 4.5 \\
\hline 13 & $\begin{array}{c}\text { Alternative } 13 \\
\text { Baribis- } \\
\text { Kendeng Fault }\end{array}$ & Weleri & $\mathrm{R}$ & 4.5 \\
\hline 14 & $\begin{array}{l}\text { Alternative } 14 \\
\text { Baribis- } \\
\text { Kendeng Fault }\end{array}$ & Semarang & $\mathrm{R}$ & 4.5 \\
\hline 15 & $\begin{array}{l}\text { Alternative } 15 \\
\text { Baribis- } \\
\text { Kendeng Fault }\end{array}$ & $\begin{array}{l}\text { Rawa } \\
\text { Pening }\end{array}$ & $\mathrm{R}$ & 4.5 \\
\hline 16 & $\begin{array}{l}\text { Alternative } 16 \\
\text { Baribis- } \\
\text { Kendeng Fault }\end{array}$ & Demak & $\mathrm{R}$ & 4.5 \\
\hline 17 & $\begin{array}{l}\text { Alternative } 17 \\
\text { Baribis- } \\
\text { Kendeng Fault }\end{array}$ & Purwodadi & $\mathrm{R}$ & 4.5 \\
\hline 18 & $\begin{array}{l}\text { Alternative } 18 \\
\text { Baribis- } \\
\text { Kendeng Fault }\end{array}$ & Cepu & $\mathrm{R}$ & 4.5 \\
\hline 19 & $\begin{array}{l}\text { Alternative } 19 \\
\text { Baribis- } \\
\text { Kendeng Fault }\end{array}$ & Waru & $\mathrm{R}$ & 4.5 \\
\hline 20 & Alternative 20 & Surabaya & $\mathrm{R}$ & 4.5 \\
\hline
\end{tabular}

\begin{tabular}{|c|c|c|c|c|}
\hline & $\begin{array}{c}\text { Baribis- } \\
\text { Kendeng Fault }\end{array}$ & & & \\
\hline 21 & $\begin{array}{l}\text { Alternative } 21 \\
\text { Baribis- } \\
\text { Kendeng Fault }\end{array}$ & Blumbang & $\mathrm{R}$ & 4.5 \\
\hline 22 & $\begin{array}{l}\text { Alternative } 22 \\
\text { Baribis- } \\
\text { Kendeng Fault }\end{array}$ & Tampo Mas & $\mathrm{N}$ & 4.5 \\
\hline 23 & $\begin{array}{l}\text { Alternative } 22 \\
\text { Baribis- } \\
\text { Kendeng Fault }\end{array}$ & Kendeng & $\mathrm{R}$ & 5 \\
\hline 24 & $\begin{array}{c}\text { Alternative } 24 \\
\text { Opak Fault }\end{array}$ & Opak & SS & 5 \\
\hline 25 & $\begin{array}{c}\text { Alternative } 25 \\
\text { Muria Fault }\end{array}$ & Muria & $\mathrm{N}$ & 2 \\
\hline 26 & $\begin{array}{l}\text { Alternative } 26 \\
\text { Ciremai Fault }\end{array}$ & Ciremai & SS & 0.5 \\
\hline 27 & $\begin{array}{c}\text { Alternative } 27 \\
\text { Ajibarang } \\
\text { Fault }\end{array}$ & Ajibarang & SS & 0.5 \\
\hline 28 & $\begin{array}{l}\text { Alternative } 28 \\
\text { Ungaran Fault }\end{array}$ & Ungaran-1 & $\mathrm{N}$ & 0.1 \\
\hline 29 & $\begin{array}{l}\text { Alternative } 29 \\
\text { Ungaran Fault }\end{array}$ & Ungaran-2 & $\mathrm{N}$ & 0.1 \\
\hline 30 & $\begin{array}{c}\text { Alternative } 30 \\
\text { Merapi- } \\
\text { Merbabu }\end{array}$ & $\begin{array}{l}\text { Merapi- } \\
\text { Merbabu }\end{array}$ & SS & 1.0 \\
\hline 31 & $\begin{array}{c}\text { Alternative } 31 \\
\text { Pati Fault } \\
\end{array}$ & Pati & SS & 0.1 \\
\hline 32 & $\begin{array}{c}\text { Alternative } 32 \\
\text { Pasuruan Fault }\end{array}$ & Pasuruan & $\mathrm{N}$ & 0.2 \\
\hline 33 & $\begin{array}{c}\text { Alternative } 33 \\
\text { Probolinggo } \\
\text { Fault }\end{array}$ & Probolinggo & $\mathrm{N}$ & 0.2 \\
\hline 34 & $\begin{array}{c}\text { Alternative } 34 \\
\text { Wonorejo } \\
\text { Fault }\end{array}$ & Wonorejo & $\mathrm{N}$ & 0.3 \\
\hline
\end{tabular}

Table 3 below showed the result of multicriteria analysis with 6 criterions and its average rating.

Table 3. Criterion of Faults Priority Analysis

\begin{tabular}{|c|c|c|}
\hline $\begin{array}{c}\text { Criterion 1 } \\
\text { Rating } \\
\text { Magnitude }\end{array}$ & $\begin{array}{c}\text { Criterion 2 } \\
\text { Rating } \\
\text { Region }\end{array}$ & $\begin{array}{c}\text { Crit aerion 3 } \\
\text { Rating } \\
\text { Population } \\
\text { Density }\end{array}$ \\
\hline 3 & 2 & 2 \\
\hline 3 & 1 & 1 \\
\hline 3 & 1 & 1 \\
\hline 3 & 3 & 3 \\
\hline 1 & 2 & 2 \\
\hline 1 & 2 & 2 \\
\hline 1 & 2 & 2 \\
\hline 1 & 1 & 1 \\
\hline 3 & 2 & 2 \\
\hline 3 & 2 & 2 \\
\hline 3 & 2 & 2 \\
\hline 3 & 2 & 2 \\
\hline 3 & 1 & 1 \\
\hline 3 & 3 & 3 \\
\hline 3 & 1 & 1 \\
\hline 3 & 2 & 2 \\
\hline 3 & 2 & 2 \\
\hline 3 & 2 & 2 \\
\hline 3 & 1 & 1 \\
\hline & & \\
\hline
\end{tabular}




\begin{tabular}{|l|l|l|}
\hline 3 & 3 & 3 \\
\hline 3 & 1 & 1 \\
\hline 3 & 1 & 1 \\
\hline 3 & 1 & 1 \\
\hline 3 & 3 & 3 \\
\hline 1 & 1 & 1 \\
\hline 1 & 1 & 1 \\
\hline 1 & 1 & 1 \\
\hline 1 & 1 & 1 \\
\hline 1 & 1 & 1 \\
\hline 1 & 1 & 1 \\
\hline 1 & 2 & 2 \\
\hline 1 & 2 & 2 \\
\hline 1 & 2 & 2 \\
\hline 1 & 1 & 1 \\
\hline
\end{tabular}

\begin{tabular}{|c|c|c|c|}
\hline $\begin{array}{l}\text { Criterion } 4 \\
\text { Rating } \\
\text { Education } \\
\text { Level } \\
\end{array}$ & $\begin{array}{c}\text { Criterion } 5 \\
\text { Rating } \\
\text { Infrastructure }\end{array}$ & $\begin{array}{c}\text { Criterion } 6 \\
\text { Rating } \\
\text { Economic Level }\end{array}$ & $\begin{array}{c}\text { Average } \\
\text { Rating }\end{array}$ \\
\hline 2 & 2 & 2 & 2.17 \\
\hline 1 & 1 & 1 & 1.33 \\
\hline 1 & 1 & 1 & 1.33 \\
\hline 3 & 3 & 3 & 3 \\
\hline 2 & 2 & 2 & 1.83 \\
\hline 2 & 2 & 2 & 1.83 \\
\hline 2 & 2 & 2 & 1.83 \\
\hline 1 & 1 & 1 & 1 \\
\hline 2 & 2 & 2 & 2.17 \\
\hline 2 & 2 & 2 & 2.17 \\
\hline 2 & 2 & 2 & 2.17 \\
\hline 2 & 2 & 2 & 2.17 \\
\hline 1 & 1 & 1 & 1.33 \\
\hline 3 & 3 & 3 & 3 \\
\hline 1 & 1 & 1 & 1.33 \\
\hline 2 & 2 & 2 & 2.17 \\
\hline 2 & 2 & 2 & 2.17 \\
\hline 2 & 2 & 2 & 2.17 \\
\hline 1 & 1 & 1 & 1.33 \\
\hline 3 & 3 & 3 & 3 \\
\hline 1 & 1 & 1 & 1.33 \\
\hline 1 & 1 & 1 & 1.33 \\
\hline 1 & 1 & 1 & 3 \\
\hline 3 & 3 & 3 & 3 \\
\hline 1 & 1 & 1 & 1 \\
\hline 1 & 1 & 1 & 1 \\
\hline 1 & 1 & 1 & 1 \\
\hline 1 & 1 & 1 & 1 \\
\hline 1 & 1 & 1 & 1 \\
\hline 1 & 1 & 1 & 1 \\
\hline 2 & 2 & 2 & 1.83 \\
\hline 2 & 2 & 2 & 1.83 \\
\hline 2 & 2 & 2 & 1.83 \\
\hline 1 & 1 & 1 & 1 \\
\hline
\end{tabular}

\section{Discussion}

Based on the assessment table with multicriteria analysis as part of the decision making process for determining fault priorities on Java Island, it was found that the biggest weight in the priority analysis of active faults which had the 3 (three) values as the highest average ratings where fault locations were in large cities with high population densities, good in education level, high economic level with complete and modern infrastructure. The first level priority are Lembang Fault, Semarang Fault, Surabaya Fault, Kendeng Fault, Opak Fault, The second priority is the fault with an average rating value of 2.17 where the character of the fault has a relative magnitude of $>4$, but the fault location is at the district level where the population density is relatively not as dense as the provincial capital, the infrastructure is relatively a few and less modern, low to medium education level. The third priority is the fault with an average rating of 1.83 where the fault character has a small magnitude $<1$ but the fault location is in a district with moderate population density and little infrastructure. The fourth priority is a fault with a value of 1.33 average rating where the fault character has a magnitude $>4$ but the fault location is in an area with low population density, less infrastructure, middle to lower economic level and low to medium education level. The fifth priority is a fault with an average rating of 1 where the fault character has a low magnitude $<1$. However the fault location is in sub-district areas with low population density, little infrastructure, middle to lower economic level and lower secondary education level.

\section{Conclusion}

Java Island is passed by active land faults based on revised maps of source and earthquake hazards in Indonesia 2017 so it is necessary to do earthquake research priority mapping using the decision maker method-multi criteria analysis including criteria for magnitude, fracture location administratively, population density, infrastructure, level of education and economy. The results of the decision maker-multicriteria analysis method showed that the highest priority in fault analysis is a fault with an average rating of 3 with a high magnitude $>4$ through a large city or provincial capital with high population density, complete and modern infrastructure, and education and middle to upper economy level. For examples are Lembang fault, Opak fault, Semarang fault, Surabaya fault. The next priority is faults with an average rating of 2 with fault characteristics having a high magnitude $>4$ but different in fault locations located in cities or districts with fewer populations than the provincial capital. In addition, the priority of fault analysis is worth an average rating of around 1 with the character of high to small magnitude however the fault location is in sub-districts with a small population density, less important infrastructure, middle to lower economic and education levels.

\section{References}

1. W. Hamilton. Tectonics of the Indonesian Region, 3-10 (1973)

2. A. Satyana and M.E.M. Purwaningsih. Proccedings of Joint Convention Jakarta. (2003)

3. B. Setyadji, I. Murata, J. Kahar. Ann.Disas.Prev. Res. Ins. Kyoto Univ 40, B-1 27-33 (1997) 
4. H. Z. Abidin, H. Andreas, M. Gamal, A.D. Wirakusumah, D. Darmawan, T. Deguchi, Y. Maruyama. J. App Geod. 2(3) 167-177 (2008)

5. I. Meilano, H. Z. Abidin, H. Andreas, I. Gumilar, D. Sarsito, R. Hanifa. J.of Diss.Researc 7(1) 12-18 (2012).

6. A. Koulali, S. McClusky, S. Susilo, Y. Leonard, P. Cummins, P. Tregoning, I. Meilano, J. Efendi. And A.B. Wijanarto, Earth and Planetary Sc. Lett. 458 69-79 (2017)

7. Y. Okada. Bull.Seis. Soc.Am. 75 1135-1154 (1985)
8. H. Z. Abidin, H. Andreas, I. Kato, T. Ito, I. Meilano, F. Kimata, D. H. Natawidjaya J. Earthq.Tsunami 3(2) 77-88 (2009)

9. Decision Making Tools and Techniques. A Guide to Assessing Needs Sect 3B

10. V. Belton, T. Stewart. Multiple Criteria Decision Analysis-An integrated Approach. (Kluwer Academic Press, 2002)

11. D. Baker, D. Bridges, R. Hunter, G. Johnson, J. Krupa, J. Murphy, and K. Sorenson. Guidebook to Decision Making Methods. (Department of Energy, USA, 2002)

12. J. Fulop. Introduction to Decision Making Methods. 